Fatmawati, Purnawarman, and Sukyadi,

Tell : Teaching of English Language and Literature Journal

Vol. 9, No.2, September 2021, Doi: http://dx.doi.org/10.30651/tell.v9i2.9305

\title{
Formative Assessment and Self-Regulated Learning during Pandemic Era
}

\author{
Ai Fatmawati \\ Universitas Pendidikan Indonesia, Indonesia \\ Aifatma96@upi.edu
}

Pupung Purnawarman

Universitas Pendidikan Indonesia, Indonesia

Pupung@upi.edu

Didi Sukyadi

Universitas Pendidikan Indonesia, Indonesia

dsukyadi@upi.edu

\section{Article History}

Received: 04 August 2021

Reviewed: 21 August 2021

Accepted: 31 August 2021

Published: 30 September 2021

\begin{abstract}
Highlights
During online learning students need to have selfregulated learning which can be promoted through the implementation of formative assessment
\end{abstract}

\begin{abstract}
During online learning in Covid-19 outbreak, self-regulation is needed more due to the different learning situation and distance between student and teacher. One of the ways to support student self-regulated learning in EFL classes is through the implementation of formative assessment. The aim of this study is to find out the formative assessment that EFL teachers use in online learning and how they perceive the role of formative assessment in supporting students' self-regulated learning. To get the data, questionnaire adapted from Gan et al. (2019); Pat-El et al. (2013) was utilized. Interviews also were conducted to get deeper understanding about the findings obtained through questionnaire. The findings revealed that during online learning, EFL teachers used a variety of formative assessment techniques, using online platforms that were easy to use. They agreed that students need to have self-regulated learning skills during online learning. However, some of them did not know for sure that the formative assessment they conducted could enhance students' self-regulated learning since only some students submitted their work. Further research can be done to find out strategies to implement formative assessment using technologies or tools utilized in online learning where the students can get immediate feedback and use it to help them improve their learning.

Keywords: formative assessment, self-regulated learning, online learning
\end{abstract}

\section{Introduction}

Since Covid-19 pandemic outbreak spread around the country, the ministry of education in Indonesia has determined to implement online learning, specifically in the areas affected by it, to reduce the virus spread. Students are facing a new situation. All interaction between teacher and student such as providing and explaining the materials, providing assignments, or studentteacher discussion will be implemented through online (Allo, 2020). It creates a new challenge for both students and teachers since it happens in a sudden and fully unprepared situation (Atmojo \& Nugroho, 2020). Online learning encourages "the reconstruction of student and instructor roles, relations, and practices" (Vonderwell \& Liang, 2007). Different from traditional face-to-face classrooms, they need to organize and self-regulate their learning autonomously in order to be successful (Inan et al., 2017; Pelikan et al., 2021).

It is suggested that during distant learning, students need to have parents' online assistance (Ariyanti, 2020). However, most parents generally work outside their home which makes it difficult for them to track, direct, and assist their children in learning to solve the problems they face (Efriana, 2021). A study conducted by Dong et al. (2020) revealed that parents perceived online learning effectiveness is low since their children's self-regulation is weak. To attain their 
Fatmawati, Purnawarman, and Sukyadi,

Tell : Teaching of English Language and Literature Journal

Vol. 9, No.2, September 2021, Doi: http://dx.doi.org/10.30651/tell.v9i2.9305

academic goals, students in online learning demand more self-direction and self-regulation in arranging their learning process because online learning is often less structured (Bol \& Garner, 2011; Pelikan et al., 2021). Therefore, it is necessary to promote students' self-regulation learning skills during this online learning in order to maximize their learning.

Yukselturk and Bulut (2007) identified the characteristics of successful online students as the ones who are aware of their responsibilities, manage their time to finish their assignments, seek help when challenges arise, and keep track on their own learning progress. It is in line to what Bjork, Dunlosky, and Kornell (2013) said that in order to be effective in the learning process, a learner must be able to effectively assess the level of their own learning as well as control their own learning and activities in response to such monitoring. In addition, Chou \& Zou (2020) found out that students with weak self-regulated learning process such as poor selfassessment and poor internal feedback result in poor learning outcomes.

Self-regulated learning can be built through a range of instructional approaches that assist and guide students in using various learning strategies (Panadero et al., 2018). It is like using outside approaches such as providing students with constructive feedback on their efforts, teaching them effective methods for addressing learning challenges either individually or collaboratively, actively promoting self-monitoring, and making learning processes more explicit (Chung \& Yuen, 2011). It can be through the assessment that the teacher utilizes during online learning. One of the assessment types that can enable students to be self-regulated learner is formative assessment (Nicol \& Macfarlane-Dick, 2006). Formative assessment strategies to promote self-regulated learning involve students in taking roles that move their learning forward by recognizing and developing specific learning targets and behavioral objectives, gathering evidence of their learning, monitoring their own progress, and giving and asking feedback (Chan et al., 2014). Granberg et al. (2021) revealed that formative assessment practice conducted by the participants had a considerable impact on both motivating attitudes and actions related to self-regulation of learning. Formative assessment activities are integrated inside instructions to monitor learning and assess learners' understanding in order to alter instruction and inform additional learning through continual and timely feedback until the target level of knowledge is achieved (Gikandi et al., 2011). It can give teachers with immediate feedback to assist students take responsibility of their learning and to enhance student learning and advancement (Vonderwell et al., 2007).

Learners become more aware of their current learning status as a result of feedback and take efforts to improve their learning (Wong et al., 2019). Formative assessment is frequently used as a source of continual feedback with the goal of improving teaching and learning (Hargreaves, 2008). It is important how teachers may structure their feedback activities and how they teach students to respond to it so that students notice the feedback, view it as meaningful, and use it (Chan et al., 2014; Van Der Kleij, 2019). Chan et al. (2014) argue that feedback is beneficial when students understand what they should do next and how to do it better. Besides that, teachers also need to teach students to use themselves and others as resources to help them achieve their learning goals. It means, teachers will not be the only resource in giving feedback to students when they are taught how to do peer-tutoring and selfevaluation. Teachers need to be able to adjust the formative assessment techniques to fit the 
Fatmawati, Purnawarman, and Sukyadi,

Tell : Teaching of English Language and Literature Journal

Vol. 9, No.2, September 2021, Doi: http://dx.doi.org/10.30651/tell.v9i2.9305

characteristics of online teaching by establishing effective assessment method and recognizing the potential of technology tools for monitoring student learning and assessing their own teaching (S. K. Vonderwell \& Boboc, 2013). Luthfiyyah et al. (2021) found out that teachers claim that technology can help them in a variety of ways, including reducing effort, providing feedback, and increasing student involvement and independent learning.

Since promoting self-regulated learning needs continuous efforts to keep students' engagement and self-efficacy (Pintrich, 1999), EFL teachers need to provide quality feedback in formative assessment as a stimulus of learning with coaching principles, empowering students' confidence and hope, then self-regulating their own learning. It indicates that students need teacher guidance to be self-regulated learner. However, during this pandemic outbreak, teacher guidance will be different from the usual classroom situation. Therefore, to add to the body of research about how teachers promote self-regulated learning through the practice of formative assessment in English classes during online learning, this current study investigates how formative assessment is conducted by the teachers during online learning in pandemic situation and how they perceive it in supporting students' self-regulated learning. The present research is guided by the following questions: (1) How do teachers implement formative assessment in online learning? (2) How do the teachers perceive the role of online formative assessment in supporting student self-regulated learning skills?

\section{Method}

This study employs a mix-method design. A mixed method design can be used to collect the best from the quantitative and qualitative approaches to examine the issue (Dessie \& Heeralal, 2016). Creswell (2014) argue that the strenghts and limitations of each data collection can be combined to generate a better understanding of the research problem. An online survey and semi-structured interviews were used in this study, as described in the following paragraphs.

The researcher first distributed questionnaire adapted from Gan et al. (2019); Pat-El et al. (2013) through google form to English teachers in Indonesia. English teachers participated in this study are from a wide range of provinces in Indonesia, but 50.5\% of them are from West Java. There were 99 English teachers who participated in this study, 55 of them are teaching in junior high school and 44 of them are teaching in senior high school. They are who have been/was teaching using online teaching during this pandemic outbreak. The questionnaire was utilized to find out how English teachers implement formative assessment during online learning and how they support student self-regulated learning during implementing formative assessment. The items of the questionnaire were reviewed by the lecturer of English education department. It consisted of 37 items with four options of response ranging from strongly disagree to strongly agree.

Besides questionnaire, the researcher also conducted interviews to get deeper understanding regarding the questionnaire findings. The interview questions were adapted from Xiao \& Yang (2019) with six questions related to the formative assessment, feedback practices as well as self-assessment encouragement. Due to the limited time and distance between the researcher and the respondents, the interviews were conducted with only five teachers. Three teachers are teaching in junior high school, and two teachers are teaching in senior high school. Hamied (2017) asserts that in qualitative data, sample is typically 
Fatmawati, Purnawarman, and Sukyadi,

Tell : Teaching of English Language and Literature Journal

Vol. 9, No.2, September 2021, Doi: http://dx.doi.org/10.30651/tell.v9i2.9305

purposive, so it does not matter how many participants are involved. The interview was conducted through Zoom and WhatsApp.

To analyze the data, the researcher compared the quantitative findings and the qualitative one. The researcher provided the questionnaire findings first, followed by a discussion of the qualitative data through the emerge themes that either confirm or disconfirm the quantitative results (Creswell, 2014).

\section{Findings and Discussion}

\section{Findings of Quantitative Data}

In the table below, the implementation of formative assessment during online learning is being described. Besides that, how the teachers scaffold and monitor the students' learning is also given.

Table 1

Items Related to Formative Assessment, Scaffolding, and Monitoring

\begin{tabular}{|c|c|c|c|c|c|}
\hline & Items & SD & $\mathbf{D}$ & $\mathbf{A}$ & $\mathbf{S A}$ \\
\hline 1 & $\begin{array}{l}\text { I evaluate student understanding after a unit of } \\
\text { instruction of a new topic. }\end{array}$ & 0 & $4(4 \%)$ & $\begin{array}{l}38 \\
(38.4 \%)\end{array}$ & $\begin{array}{l}57 \\
(57.6 \%)\end{array}$ \\
\hline 2 & $\begin{array}{l}\text { I use quizzes after a unit of instruction to check on } \\
\text { students' learning of specific knowledge items and skills. }\end{array}$ & $1(1 \%)$ & $7(7.1 \%)$ & $\begin{array}{l}48 \\
(48.5 \%)\end{array}$ & $\begin{array}{l}43 \\
(43.4 \%)\end{array}$ \\
\hline 3 & $\begin{array}{l}\text { I use a variety of questioning techniques to assess student } \\
\text { understanding of the subject content. }\end{array}$ & 0 & $9(9.1 \%)$ & $\begin{array}{l}39 \\
(39.4 \%)\end{array}$ & $\begin{array}{l}51 \\
(51.5 \%)\end{array}$ \\
\hline 4 & $\begin{array}{l}\text { I use online website like quizizz, kahoots, nearpod, or the } \\
\text { other tools to assess student understanding of the subject } \\
\text { content. }\end{array}$ & $6(6.1 \%)$ & $\begin{array}{l}14 \\
(14.1 \%)\end{array}$ & $\begin{array}{l}44 \\
(44.4 \%)\end{array}$ & $\begin{array}{l}35 \\
(35.4 \%)\end{array}$ \\
\hline 5 & $\begin{array}{l}\text { I use essay questions to assess student understanding of } \\
\text { the subject content. }\end{array}$ & $2(2 \%)$ & $\begin{array}{l}18 \\
(18.2 \%)\end{array}$ & $\begin{array}{l}51 \\
(51.5 \%)\end{array}$ & $\begin{array}{l}28 \\
(28.3 \%)\end{array}$ \\
\hline 6 & $\begin{array}{l}\text { I use oral reading/dictation to assess student } \\
\text { understanding of the subject content. }\end{array}$ & $7(7,1 \%)$ & $\begin{array}{l}35 \\
(35.4 \%)\end{array}$ & $\begin{array}{l}36 \\
(36.4 \%)\end{array}$ & $\begin{array}{l}21 \\
(21.2 \%)\end{array}$ \\
\hline 7 & $\begin{array}{l}\text { I use fill-in-the blank or short answer questions to assess } \\
\text { student understanding of the subject content. }\end{array}$ & $1(1 \%)$ & $\begin{array}{l}12 \\
(12.1 \%)\end{array}$ & $\begin{array}{l}55 \\
(55.6 \%)\end{array}$ & $\begin{array}{l}31 \\
(31.3 \%)\end{array}$ \\
\hline 8 & I assess student through observation & $3(3 \%)$ & $\begin{array}{l}16 \\
(16.2 \%)\end{array}$ & $\begin{array}{l}43 \\
(43.4 \%)\end{array}$ & $\begin{array}{l}37 \\
(37.4 \%)\end{array}$ \\
\hline 9 & I evaluate student through oral questions & $6(6.1 \%)$ & $\begin{array}{l}20 \\
(20.2 \%)\end{array}$ & $\begin{array}{l}48 \\
(48.5 \%)\end{array}$ & $\begin{array}{l}25 \\
(25.3 \%)\end{array}$ \\
\hline 10 & $\begin{array}{l}\text { I adjust my instruction whenever I notice that my } \\
\text { students do not understand a topic. }\end{array}$ & $1(1 \%)$ & $3(3 \%)$ & $\begin{array}{l}28 \\
(28.3 \%)\end{array}$ & $\begin{array}{l}67 \\
(67.7 \%)\end{array}$ \\
\hline 11 & $\begin{array}{l}\text { I provide my students with guidance to help them gain } \\
\text { understanding of the content taught }\end{array}$ & 0 & $4(4 \%)$ & $\begin{array}{l}27 \\
(27.3 \%)\end{array}$ & $\begin{array}{l}68 \\
(68.7 \%)\end{array}$ \\
\hline 12 & $\begin{array}{l}\text { During my class, students are given the opportunity to } \\
\text { show what they have learned. }\end{array}$ & $1(1 \%)$ & $2(2 \%)$ & $\begin{array}{l}41 \\
(41.4 \%)\end{array}$ & $\begin{array}{l}55 \\
(55.6 \%) \\
\end{array}$ \\
\hline 13 & I ask questions in a way my students understand. & 0 & $1(1 \%)$ & $\begin{array}{l}39 \\
(39.4 \%)\end{array}$ & $\begin{array}{l}59 \\
(59.6 \%)\end{array}$ \\
\hline 14 & $\begin{array}{l}\text { By asking questions during class, I help my students gain } \\
\text { understanding of the content taught }\end{array}$ & 0 & $3(3 \%)$ & $\begin{array}{l}33 \\
(33.3 \%)\end{array}$ & $\begin{array}{l}63 \\
(63.6 \%)\end{array}$ \\
\hline 15 & I am open to student contribution in my class & 0 & $2(2 \%)$ & $\begin{array}{l}20 \\
(20.2 \%)\end{array}$ & $\begin{array}{l}77 \\
(77.8 \%)\end{array}$ \\
\hline 16 & $\begin{array}{l}\text { I allow my students to ask each other questions during } \\
\text { class. }\end{array}$ & $1(1 \%)$ & $7(7.1 \%)$ & $\begin{array}{l}35 \\
(35.4 \%)\end{array}$ & $\begin{array}{l}56 \\
(56.6 \%)\end{array}$ \\
\hline
\end{tabular}


Fatmawati, Purnawarman, and Sukyadi,

Tell : Teaching of English Language and Literature Journal

Vol. 9, No.2, September 2021, Doi: http://dx.doi.org/10.30651/tell.v9i2.9305

\begin{tabular}{|c|c|c|c|c|c|}
\hline 17 & $\begin{array}{l}\text { I ensure that my students know what areas they need to } \\
\text { work on in order to improve their results. }\end{array}$ & 0 & $6(6.1 \%)$ & $\begin{array}{l}45 \\
(45.5 \%)\end{array}$ & $\begin{array}{l}48 \\
(48.5 \%)\end{array}$ \\
\hline 18 & I give my students opportunities to ask questions. & 0 & $1(1 \%)$ & $\begin{array}{l}14 \\
(14.1 \%)\end{array}$ & $\begin{array}{l}84 \\
(84.8 \%)\end{array}$ \\
\hline 19 & $\begin{array}{l}\text { My students know what the evaluation criteria for their } \\
\text { work are. }\end{array}$ & $1(1 \%)$ & $\begin{array}{l}12 \\
(12.1 \%)\end{array}$ & $\begin{array}{l}55 \\
(55.6 \%)\end{array}$ & $\begin{array}{l}31 \\
(31.3 \%)\end{array}$ \\
\hline 20 & $\begin{array}{l}\text { I ensure that my students know what they can learn from } \\
\text { their assignments. }\end{array}$ & $1(1 \%)$ & $3(3 \%)$ & $\begin{array}{l}45 \\
(45.5 \%)\end{array}$ & $\begin{array}{l}50 \\
(50.5 \%)\end{array}$ \\
\hline 21 & $\begin{array}{l}\text { I can recognize when my students reach their learning } \\
\text { goals. }\end{array}$ & $1(1 \%)$ & $7(7.1 \%)$ & $\begin{array}{l}54 \\
(54.5 \%)\end{array}$ & $\begin{array}{l}37 \\
(37.4 \%)\end{array}$ \\
\hline 22 & $\begin{array}{l}\text { I encourage my students to reflect upon how they can } \\
\text { improve their assignments }\end{array}$ & $1(1 \%)$ & $8(8.1 \%)$ & $\begin{array}{l}47 \\
(47.5 \%)\end{array}$ & $\begin{array}{l}43 \\
(43.4 \%)\end{array}$ \\
\hline 23 & After a test, I discuss the answers given with each student & $2(2 \%)$ & $\begin{array}{l}10 \\
(10.1 \%)\end{array}$ & $\begin{array}{l}52 \\
(52.5 \%)\end{array}$ & $\begin{array}{l}35 \\
(35.4 \%)\end{array}$ \\
\hline 24 & $\begin{array}{l}\text { While working on their assignments, I ask my students } \\
\text { how they think they are doing. }\end{array}$ & $3(3 \%)$ & $\begin{array}{l}13 \\
(13.1 \%)\end{array}$ & $\begin{array}{l}48 \\
(48.5 \%)\end{array}$ & $\begin{array}{l}35 \\
(35.4 \%)\end{array}$ \\
\hline 25 & $\begin{array}{l}\text { I involve my students in thinking about how they want to } \\
\text { learn at school. }\end{array}$ & $3(3 \%)$ & $\begin{array}{l}11 \\
(11.1 \%) \\
\end{array}$ & $\begin{array}{ll}55 \\
(55.6 \%)\end{array}$ & $\begin{array}{ll}30 \\
(30.3 \%)\end{array}$ \\
\hline 26 & $\begin{array}{l}\text { I give my students the opportunity to decide on their } \\
\text { learning objectives. }\end{array}$ & $6(6.1 \%)$ & $\begin{array}{l}24 \\
(24.2 \%) \\
\end{array}$ & $\begin{array}{l}44 \\
(44.4 \%) \\
\end{array}$ & $\begin{array}{l}25 \\
(25.3 \%) \\
\end{array}$ \\
\hline 27 & $\begin{array}{l}\text { I ask my students to indicate what went well and what } \\
\text { went badly concerning their assignments }\end{array}$ & $3(3 \%)$ & $\begin{array}{l}17 \\
(17.2 \%)\end{array}$ & $\begin{array}{l}55 \\
(55.6 \%)\end{array}$ & $\begin{array}{l}24 \\
(24.2 \%)\end{array}$ \\
\hline 28 & $\begin{array}{l}\text { I encourage students to reflect upon their learning } \\
\text { processes and how to improve their learning. }\end{array}$ & $2(2 \%)$ & $8(8.1 \%)$ & $\begin{array}{l}48 \\
(48.5 \%)\end{array}$ & $\begin{array}{l}41 \\
(41.4 \%)\end{array}$ \\
\hline 29 & $\begin{array}{l}\text { I inform my students on their strong points concerning } \\
\text { learning. }\end{array}$ & $3(3 \%)$ & $8(8.1 \%)$ & $\begin{array}{l}58 \\
(58.6 \%)\end{array}$ & $\begin{array}{l}30 \\
(30.3 \%)\end{array}$ \\
\hline 30 & $\begin{array}{l}\text { I inform my students on their weak points concerning } \\
\text { learning. }\end{array}$ & $1(1 \%)$ & $\begin{array}{l}14 \\
(14.1 \%)\end{array}$ & $\begin{array}{l}56 \\
(56.6 \%)\end{array}$ & $\begin{array}{l}28 \\
(28.3 \%)\end{array}$ \\
\hline 31 & $\begin{array}{l}\text { I encourage my students to improve on their learning } \\
\text { processes }\end{array}$ & $1(1 \%)$ & $2(2 \%)$ & $\begin{array}{l}29 \\
(29.3 \%)\end{array}$ & $\begin{array}{l}67 \\
(67.7 \%) \\
\end{array}$ \\
\hline 32 & I give students guidance and assistance in their learning. & $1(\%)$ & $2(2 \%)$ & $\begin{array}{l}41 \\
(41.4 \%)\end{array}$ & $\begin{array}{l}55 \\
(55.6 \%)\end{array}$ \\
\hline 33 & $\begin{array}{l}\text { I discuss assignments with my students to help them } \\
\text { understand the content better. }\end{array}$ & $3(3 \%)$ & $4(4 \%)$ & $\begin{array}{l}43 \\
(43.4 \%)\end{array}$ & $\begin{array}{l}49 \\
(49.5 \%)\end{array}$ \\
\hline 34 & I discuss with my students the progress they have made & $3(3 \%)$ & $6(6.1 \%)$ & $\begin{array}{l}48 \\
(48.5 \%)\end{array}$ & $\begin{array}{l}42 \\
(42.4 \%)\end{array}$ \\
\hline 35 & $\begin{array}{l}\text { After an assessment, I inform my students on how to } \\
\text { improve their weak points }\end{array}$ & $4(4 \%)$ & $\begin{array}{l}11 \\
(11.1 \%)\end{array}$ & $\begin{array}{l}50 \\
(50.5 \%)\end{array}$ & $\begin{array}{l}34 \\
(34.3 \%)\end{array}$ \\
\hline 36 & $\begin{array}{l}\text { I discuss with my students how to utilize their strengths } \\
\text { to improve on their assignment }\end{array}$ & $1(1 \%)$ & $\begin{array}{l}14 \\
(14.1 \%)\end{array}$ & $\begin{array}{l}45 \\
(45.5 \%)\end{array}$ & $\begin{array}{l}39 \\
(39.4 \%)\end{array}$ \\
\hline 37 & $\begin{array}{l}\text { Together with my students, I consider ways on how to } \\
\text { improve on their weak points }\end{array}$ & $5(5.1 \%)$ & $\begin{array}{l}11 \\
(11.1 \%)\end{array}$ & $\begin{array}{l}52 \\
(52.5 \%)\end{array}$ & $\begin{array}{l}31 \\
(31.3 \%)\end{array}$ \\
\hline
\end{tabular}

As table 1 presents, items number 2 until 9 refer to how teachers implement formative assessment during online learning. It indicates that quizzes (96\%), questioning techniques (90.9\%), online websites such as Quizizz, Kahoot, Nearpod and other tools (79.8\%), essay question $(79,8 \%)$, fill-in-the blank or short answer questions (86.9\%), observation (80.8), and oral questions $(73.8 \%)$ are the types of assessments that most teachers use during online learning. Oral reading/dictation, on the other hand, is the least desired evaluation method utilized by teachers in their classes $(57.6 \%)$. 
Fatmawati, Purnawarman, and Sukyadi,

Tell : Teaching of English Language and Literature Journal

Vol. 9, No.2, September 2021, Doi: http://dx.doi.org/10.30651/tell.v9i2.9305

Questionnaire items number 10 until 21 in table 1 above are related to scaffolding used by the teachers in the class. The table shows that $28.3 \%$ agree and $67.7 \%$ strongly agree with item number 10 . Similarly, $27.3 \%$ agree and $68.7 \%$ strongly agree with item number 11 . It can be seen that $41.4 \%$ agree and $55.6 \%$ strongly agree with item number 12 . Meanwhile, item 13 is agreed by $39.4 \%$ and strongly agreed by $59.6 \%$ of the teachers, and $33.3 \%$ agree and $63.6 \%$ strongly agree with item number 14 .

Item 15 is agreed by $20.2 \%$ and strongly agreed by $77.8 \%$ of the teachers, and $35.4 \%$ agree and $56.6 \%$ strongly agree with item number 16 . For item number $17,45.5 \%$ agree and $48.5 \%$ strongly agree. Meanwhile, item 18 is agreed by $14.1 \%$ and strongly agreed by $84.8 \%$ of the teachers. Similarly, 55.6\% agree and $31.3 \%$ strongly agree with item number 19 , and $45.5 \%$ agree and $50.5 \%$ strongly agree with item number 20 . For item number $21,54.5 \%$ of the teachers agree and $37.4 \%$ strongly agree with it. It can be seen that teachers mostly agree that they manage scaffolding during their online learning.

Questionnaire items number 22 until 37 presents how teachers monitor their student learning and progress during online learning. It shows that $47.5 \%$ agree and $43.4 \%$ strongly agree with item number 22 while $52.5 \%$ agree and $35.4 \%$ strongly agree with item 23 . Item 24 is agreed by $48.5 \%$ and strongly agreed by $35.4 \%$ of the teachers. Similarly, item 25 is agreed by $55.6 \%$ and strongly agreed by $30.3 \%$ of the teachers. For item number $26,44.4 \%$ agree and $25.3 \%$ strongly agree with it. Likewise, $55.6 \%$ agree and $24.2 \%$ strongly agree with item number $27.48 .5 \%$ agree and $41.4 \%$ strongly disagree with item number 28 , and $58.6 \%$ agree and $30.3 \%$ strongly agree with item number 29. Meanwhile, for item 30, 56.6\% agree and $28.3 \%$ strongly agree. Item 31 is agreed by $29.3 \%$ and strongly agreed by $67.7 \%$ of the teachers. Item 32 is agreed by $41.4 \%$ and strongly agreed by $55.6 \%$. Similarly, $43.4 \%$ agree and $49.5 \%$ strongly agree with item $33.48 .5 \%$ agree and $42.4 \%$ strongly agree with item number 34 . For item number 35, 50.5\% agree and 34.3\% strongly agree. Meanwhile, item 36 is agreed by $45.5 \%$ and strongly agreed by $39.4 \%$ of the teachers, and $52.5 \%$ agree and $31.3 \%$ strongly agree with item 37 . It can be seen that teachers mostly agree that they monitor their student learning during this online learning.

\section{Findings of Qualitative Data}

\section{Formative assessment practice and student self-regulation}

The findings found in quantitative data are also confirmed by the data shown in the qualitative one. The quantitative data shows that most of the teachers use several ways to conduct formative assessment. It is stated in questionnaire items number 2, 3, 4, 5, 6, 7, 8, and 9. During this pandemic, since they are conducting online learning which separates the teachers and the students, some tools like WhatsApp, google classroom, or google form are used. Teacher 1 and 2 pointed out:

"I use some applications that are easy for my students to use, as like google classroom, google form, WA to conduct the assessment."

"Usually I use g-form to assess my students."

Besides those tools, teacher 4 also use some online websites such as Peardeck and Nearpod. They pointed out: 
Fatmawati, Purnawarman, and Sukyadi,

Tell : Teaching of English Language and Literature Journal

Vol. 9, No.2, September 2021, Doi: http://dx.doi.org/10.30651/tell.v9i2.9305

"Formative assessment is usually done at the end of the lesson whether we post the link for the quizzes, or we put the task in google classroom. We also put the exercise in the Peardeck or Nearpod so during the explanation of the materials we give them questions to make sure that they understand."

In conducting the assessment, the teachers need to connect it to the learning goals. So, the assessment will be different for each chapter. It is mentioned by teacher 5 and 1 . They pointed out:

"Actually, I have a flexibility in conducting formative assessment. It does not always have to be in written test, but I can use project, portfolio or a quiz. It depends on the chapter as well. For example, the topic is about congratulating and complimenting others. I see the goals of the learning. The goal for that chapter is to be able to use it, to be able to compliment or congratulate others. I think when the assessment is in written test, students will get difficulty in applying it to their social contexts, so I prefer to conduct the project one, such as making videos with their family members to congratulate or to compliment them. I give them freedom to create their own videos." (Teacher 5)

"The assessments mostly involved productive skills where they need to work on something or perform something such as storytelling. " (Teacher 1)

\section{Feedback practices}

Questionnaire items number 29, 30, 31, 32, 35, 36, 37 shows how teachers help students to improve their learning by giving them feedback as well as how to use the feedback. Quantitative data shows mostly teachers agree with those items. To help students improve their learning, teachers will provide the students some feedback related to their assignments. During online learning, monitoring student learning is not as easy as like the face-to-face one. Teachers find it hard to monitor student learning due to the distance between them. Because of that, the feedback given to the students mostly takes place when the students have finished their assignment.

"Since students do the assignment or project at home, only some of them will text me when they have difficulties in doing the assignment. When they text me to ask about it, I will help them to finish that. It is different when we have offline classes. I usually will go around the class and check each student progress." (Teacher 2)

"When I had my offline class, I usually monitor the progress of the students in doing their assignments, but during this online learning, only some students will report their progress in doing their tasks. So, I will only ask the students who give me the report. I will ask them how far they have made the task or whether they find difficulty in finishing it. I will give them some suggestions as well." (Teacher 4)

However, teacher 5 always give the feedback during the process of doing the assignment through written or indirect feedback. Besides correcting students' tasks, she also put positive affirmation. "For students who got under certain criteria, I will give them constructive feedback. I will only give positive affirmation, like good job and so on if the students have got good achievement or above the certain criteria."

During online learning, teachers need to improve their creativity in delivering the material or the instructions to help students understand it better. The feedback given to the students 
Fatmawati, Purnawarman, and Sukyadi,

Tell : Teaching of English Language and Literature Journal

Vol. 9, No.2, September 2021, Doi: http://dx.doi.org/10.30651/tell.v9i2.9305

mostly talks about students' work or performance, as well as how to do the tasks or how to cope the problems that students find. They will find what is good and less from the assignment in order to find ways to improve it.

"The feedback gave students clearer description of what they should do regarding the tasks. To help the students make use of the feedback, I try to ask them what they have done and what they can do next." (Teacher 1)

"I will analyze the students' problems first. I will ask about their difficulties. Then, I will help them solve it. I will tell them the steps to make their work better" (Teacher 3)

"Usually, I give students feedback after I give them score and I will try to find which part that students still make a lot of mistakes, and I will explain it the next meeting. Or usually when the assessment is through Google Form, I will use the automatic ad-on scoring system and I will share the correct answer in that platform, or I will correct for example when students mistype or misspell the words." (Teacher 4)

Teachers' feedback can be used to overcome students' problem. However, not all students can use the feedback by themselves. It then makes the feedback less effective.

"I am afraid that the feedback is not really have that good impact for the students. for some occasion, I ask them whether they read the feedback on the google classroom or not and most of them just neglect it. What they think is that they submit the worksheet or the task. So here I cannot see the feedback is really like helpful for some students but let's say for the particular students, it helps but the percentage is not as many as those who just neglect it." (Teacher 4)

In the case of teacher 5, students will get special class for remedial or individual tutoring when they still got lack of achievement or understanding about the material after receiving feedback during the class. What becomes other problems for the teacher is not all students submit the assignment. Whereas teachers can see whether the feedback is effective or not by students' improvement on another task.

"I cannot tell whether what I did was effective or not, since there were only few of the students actually did the tasks. For example, when I told them to select one story from a particular website and record themselves reading the story, only few of them submitted their video recordings." (Teacher 1 )

"Only 50\% of the students who do the tasks.." (Teacher 3)

Due to the problem above, teachers agree that students need to have self-regulation during online learning because teachers cannot fully control their learning. Their self-regulation can be seen from the submission of their assignments. Teacher 3 argues what makes formative assessment become less effective to support students' self-regulation is because some of the students do not submit the assignment. Meanwhile, teacher 4 has different argument.

"Most formative assessment that I conducted is based on project whether it is making dialogue or miming dialogue in the form of video. They of course need practice first. That practices that I think will enhance their self-regulation in learning." (Teacher 4)

Teacher 5 argues that to help students develop their self-regulation, teacher can help them in learning by doing scaffolding to tell them what they should do afterwards. 
Fatmawati, Purnawarman, and Sukyadi,

Tell : Teaching of English Language and Literature Journal

Vol. 9, No.2, September 2021, Doi: http://dx.doi.org/10.30651/tell.v9i2.9305

"For example, when teaching about narrative text, I will not ask them to directly write or create narrative text. I will apply some steps before asking them write it, such as analyzing the language features and so on." (Teacher 5)

From the scaffolding given to the students, she argues that it will help her find students' weaknesses and strengths which will help her determine what feedback should be given.

\section{Self-assessment encouragement}

The questionnaire items number 22, 24, 26, and 28 shows that most of the respondents agree to encourage students to do self-assessment to see what and how they have learned. It is to help both the teacher and the students in improving their teaching and learning.

"I tell my students self-assessment is something important since it can help them to overcome the problem. It also gives teacher information to finally help their difficulty." (Teacher 2)

"In the end of the chapter, I give a self-assessment worksheet to students fill. Students with middle/high achiever mostly know what is good and less good of their learning. However, most low achiever students will only say I do not know, or I did not face any difficulty, but their assignment results show the difference. Students' self-assessment helps me improve my teaching since it provides students' weaknesses and strengths." (Teacher 5)

Encouraging students to do self-assessment is important since teachers argue it can be utilized to motivate students' learning and to find students' weaknesses and strengths so students can determine what steps should be taken to improve their achievement, as well as to achieve students' learning goals.

"To help the students come up with a learning goal, I made sure that they know what they were doing and let them think what to expect from performing such tasks." (Teacher 1)

"Self-assessment can increase students' learning motivation in class. I will give an opinion on the results of their assessment, so they know their strengths and weaknesses in the learning process and they can determine what steps should be taken to improve their learning achievement." (Teacher 2)

Some teachers perhaps do not provide explicit encouragement or motivation for students to do self-assessment, as what is illustrated in the excerpt below:

"What I said to my students is if my students let's say if you can understand someone who speak English and then you can respond to that conversation, then you can judge or measure yourself as you are already good in English and you can understand in English. Those are the things that I always say to my students, whether they listen to the song or while they watch the movie without subtitle and they understand what the movies are about, and I say to them that they have good English." (Teacher 4)

\section{Discussion}

The aim of this current study is to explore how teachers implement formative assessment during online learning as well as how they perceive the role of online formative assessment in supporting students' self-regulated learning. The findings reveal that most of teachers conduct the assessment after a unit of instruction of a new topic during online learning. They use a variety of formative assessment techniques based on the learning goals that they want to achieve. From the interview findings, they used the platforms that are easy to use, such as WhatsApp, Google Classroom, Google Form, Nearpod, Peardeck, and others. 
Fatmawati, Purnawarman, and Sukyadi,

Tell : Teaching of English Language and Literature Journal

Vol. 9, No.2, September 2021, Doi: http://dx.doi.org/10.30651/tell.v9i2.9305

Based on the questionnaire data, it can be seen that teachers monitor student learning by guiding them in understanding the topic or providing them the opportunities to ask questions or show how far they have understood the topic as well as the feedback regarding on students' performance, how to do the tasks, or how to solve their problems in doing the tasks. The feedback will be given after students have submitted the tasks. Beaumont et al. (2011) revealed that teachers emphasized the value of individual learning and used a system that gave feedback as a post-submission, summative event, but students wanted more thorough instruction. Van der Kleij (2019) stated the similar findings, that students want in terms of feedback and what can be actually accomplished in a classroom environment. Based on the interview data, among five teachers, only 1 teacher usually gave students feedback during students' learning process. Most of them seldom monitor students' progress while students are doing the assignments. They will guide students in the middle of doing the tasks when the students text the teachers through personal chats. It is not easy to check on students' work one by one during online learning due to the distance between them. Whereas feedback can serve as a scaffolding or external regulation to help students reflect on and evaluate whether there is a gap between their present performance and a desired performance objective, as well as control their learning to close the gap if one exists (Chou \& Zou, 2020).

Teachers through interview reveal that they can see that the feedback they given worked when students improved their achievement. However, some of them did not think that their feedback gave the students improvement. One teacher said that most students did not pay attention to the feedback since they only focus on submitting the work. In addition, some of the students did not submit the tasks. It is in line with the findings of a study conducted by Beaumont et al (2011) that teachers argued that students frequently failed to turn in homework and did not appear to pay attention to comments. Pelikan et al. (2021) in his study revealed that students in online learning lacked necessary knowledge to complete all required tasks and that they were easily distracted and exhausted. Therefore, how teachers may structure their feedback activities so that students notice input, view it as meaningful, and use it becomes important (Van Der Kleij, 2019).

Based on the interview findings, most teachers agree that during online learning, students need to have self-regulated learning skills. It is supported by the questionnaire findings. Students with low general self-regulated learning skills, poor calibration skills, and executive function deficits may be more vulnerable during online learning that is primarily independent or self-directed (Bol \& Garner, 2011). Some of them believed that formative assessment they use can help students increase their self-regulated learning. Some of them who did not think formative assessment can support students' self-regulated learning was because not all students submit the tasks. It means only some students who have awareness on their responsibility of doing and submitting their tasks. However, it can also be because teachers lack a wide understanding of how to promote self-regulated learning, so they do not cover both aspects of building self-regulation in their students (Ewijk \& van der Werf, 2012).

Students who have self-regulated learning skills are able to do self-assessment to find out their strengths and weaknesses that should be improved. To help students assess themselves, teachers often encourage them to do that. Among five teachers, only one teacher provided 
Fatmawati, Purnawarman, and Sukyadi,

Tell : Teaching of English Language and Literature Journal

Vol. 9, No.2, September 2021, Doi: http://dx.doi.org/10.30651/tell.v9i2.9305

students self-assessment worksheet after a new topic has been discussed. It is in line with what Chan et al. (2014) stated that teaching students to use a provided checklist of assignment requirements is a relatively simple method to expose them to self-evaluation since it can be used by students to judge whether their performance fits the learning objectives. Other teachers did not explain how they actually support students in doing self-assessment. As self- and peerassessment tools do not always improve learning, it is critical to provide teachers with guidelines for developing effective tools and teaching students on how to use them (Panadero et al., 2016). It is also stated by Vattøy (2020) that teachers need to be more aware of selfregulatory strategies across subject areas.

\section{Conclusion}

The current study findings give contribution to the literature on how formative assessment can support students' self-regulated learning during online learning. It revealed that teachers implement formative assessment during online learning through a variety of assessment techniques using technological tools that are easy to use, such as WhatsApp, Google Form, Google Classroom, and other online quiz tools. They implement it after a new unit of instructions. Among formative assessment techniques, oral reading/dictation is the least desired evaluation method used by teachers. Based on the questionnaire findings, teachers support students' self-regulated learning through monitoring and scaffolding their learning process. Different from the face-to-face instruction, teachers could not directly monitor each student's progress during the assessment projects, so they did not know the difficulties their students faced unless they themselves told the teachers through personal chats. That is why teachers delivered the feedback mostly after the students have submitted their tasks. Since not all students submitted the tasks and understood how to use the feedback, the effectiveness of the feedback is still questioned. Whereas feedback will not lead to improvement if the students do not understand the feedback and how to use it (Brookhart, 2001).

To have self-regulation, students also need to be able to do self-evaluation so that students know their strengths and weaknesses. Nevertheless, among five teachers, only one teacher provided students self-assessment worksheet to evaluate themselves. Teachers need to be trained on how to encourage and facilitate students to do self-assessment since to be selfregulated learners, doing self-assessment is a must so that they understand how to monitor their learning. More researchers need to find out the strategies to implement formative assessment using technologies or tools implemented in online learning where the students can get immediate feedback and use it to help them improve their learning. As what Gaylard Baleni (2015) said that formative assessment can help students measure their own progress; and the appropriate assessment strategies with engaging technology can be a powerful way to make learning more efficient (Mohamadi, 2018).

\section{References}

Allo, M. D. G. (2020). Is the online learning good in the midst of Covid-19 pandemic? The case of EFL learners. Jurnal Sinestesia, 10(1), 1-10.

Ariyanti, A. (2020). EFL Students' Challenges towards Home Learning Policy During Covid19 Outbreak. IJELTAL (Indonesian Journal of English Language Teaching and Applied Linguistics), 5(1), 167. https://doi.org/10.21093/ijeltal.v5i1.649 
Fatmawati, Purnawarman, and Sukyadi,

Tell : Teaching of English Language and Literature Journal

Vol. 9, No.2, September 2021, Doi: http://dx.doi.org/10.30651/tell.v9i2.9305

Atmojo, A. E. P., \& Nugroho, A. (2020). EFL classes must go online! Teaching activities and challenges during COVID-19 pandemic in Indonesia. Register Journal, 13(1), 49-76. https://doi.org/10.18326/rgt.v13i1.49-76

Beaumont, C., O’Doherty, M., \& Shannon, L. (2011). Reconceptualising assessment feedback: A key to improving student learning? Studies in Higher Education, 36(6), 671-687. https://doi.org/10.1080/03075071003731135

Bjork, R. A., Dunlosky, J., \& Kornell, N. (2013). Self-regulated learning: Beliefs, techniques, and illusions. Annual Review of Psychology, 64, 417-444. https://doi.org/10.1146/annurev-psych-113011-143823

Bol, L., \& Garner, J. K. (2011). Challenges in supporting self-regulation in distance education environments. Journal Computer High Education, 23, 104 - 123.

Brookhart, S. M. (2001). Successful students' formative and summative uses of assessment information. Assessment in Education: Principles, Policy \& Practice, 8(2), 153-169. https://doi.org/10.1080/09695940123775

Chan, P. E., Graham-Day, K. J., Ressa, V. A., Peters, M. T., \& Konrad, M. (2014). Beyond involvement: Promoting student ownership of learning in classrooms. Intervention in School and Clinic, 50(2), 105-113. https://doi.org/10.1177/1053451214536039

Chou, C. Y., \& Zou, N. B. (2020). An analysis of internal and external feedback in selfregulated learning activities mediated by self-regulated learning tools and open learner models. International Journal of Educational Technology in Higher Education, 17(1). https://doi.org/10.1186/s41239-020-00233-y

Chung, Y. B., \& Yuen, M. (2011). The role of feedback in enhancing students' self-regulation in inviting schools. Journal of Invitational Theory and Practice $\bullet, 17,22-27$.

Creswell, J. W. (2014). Research design: Qualitative, quantitative, and mixed method approaches. SAGE Publications, Inc.

Dessie, A. A., \& Heeralal, P. J. H. (2016). Formative assessment and learning: Science teachers' perception at East Gojjam preparatory schools, Amhara Regional State, Ethiopia. International Journal for Innovation Education and Research, 4(10), 70-80.

Dong, C., Cao, S., \& Li, H. (2020). Young children's online learning during COVID-19 pandemic: Chinese parents' beliefs and attitudes. Children and Youth Services Review, 118, 1-9. https://doi.org/10.1016/j.childyouth.2020.105440

Efriana, L. (2021). Problems of online learning during Covid-19 pandemic in EFL classroom and the solution. Journal of English Language Teaching and Literature, 2(1), 38-47.

Ewijk, D. C., \& van der Werf, G. (2012). What teachers think about self-regulated learning: Investigating teacher beliefs and teacher behavior of enhancing students' self-regulation. Education Research International, 2012, 1-10. https://doi.org/10.1155/2012/741713

Gan, Z., He, J., \& Liu, F. (2019). Understanding classroom assessment practices and learning motivation in secondary EFL students. Journal of Asia TEFL, 16(3), 783-800. https://doi.org/10.18823/asiatefl.2019.16.3.2.783

Gaylard Baleni, Z. (2015). Online formative assessment in higher education: Its pros and cons. Electronic Journal of E-Learning, 13(4), 228-236.

Gikandi, J. W., Morrow, D., \& Davis, N. E. (2011). Online formative assessment in higher education: A review of the literature. Computers and Education, 57(4), 2333-2351. https://doi.org/10.1016/j.compedu.2011.06.004

Granberg, C., Palm, T., \& Palmberg, B. (2021). A case study of a formative assessment practice and the effects on students' self-regulated learning. Studies in Educational Evaluation, 68, 1-10. https://doi.org/10.1016/j.stueduc.2020.100955

Hamied, F. A. (2017). Research methods: A guide for first-time researchers. UPI Press.

Hargreaves, E. (2008). Assessment. In G. McCulloch, \& D. Crook (Eds.), The Routledge 
Fatmawati, Purnawarman, and Sukyadi,

Tell : Teaching of English Language and Literature Journal

Vol. 9, No.2, September 2021, Doi: http://dx.doi.org/10.30651/tell.v9i2.9305

international encyclopaedia of education (pp. 37-38). Routledge.

Inan, F., Yukselturk, E., Kurucay, M., \& Flores, R. (2017). The impact of self-regulation strategies on student success and satisfaction in an online course. International Journal on E-Learning: Corporate, Government, Healthcare, and Higher Education, 16(1), 2332.

Luthfiyyah, R., Aisyah, A., \& Sulistyo, G. H. (2021). Technology-enhanced formative assessment in higher education: A voice from Indonesian EFL teachers. EduLite: Journal of English Education, Literature and Culture, 6(1), 42-54. https://doi.org/10.30659/e.6.1.42-54

Mohamadi, Z. (2018). Comparative effect of online summative and formative assessment on EFL student writing ability. Studies in Educational Evaluation, 59, 29-40. https://doi.org/10.1016/j.stueduc.2018.02.003

Nicol, D. J., \& Macfarlane-Dick, D. (2006). Formative assessment and self-regulated learning: A model and seven principles of good feedback practice. Studies in Higher Education, 31(2), 199-218.

Panadero, E., Andrade, H., \& Brookhart, S. (2018). Fusing self-regulated learning and formative assessment: A roadmap of where we are, how we got here, and where we are going. Australian Educational Researcher, 45(1), 13-31. https://doi.org/10.1007/s13384018-0258-y

Pat-El, R. J., Tillema, H., Segers, M., \& Vedder, P. (2013). Validation of assessment for learning questionnaires for teachers and students. British Journal of Educational Psychology, 83(1), 98-113. https://doi.org/10.1111/j.2044-8279.2011.02057.x

Pelikan, E. R., Lüftenegger, M., Holzer, J., Korlat, S., Spiel, C., \& Schober, B. (2021). Learning during COVID-19: The role of self-regulated learning, motivation, and procrastination for perceived competence. Zeitschrift Fur Erziehungswissenschaft, 24, 393-418. https://doi.org/10.1007/s11618-021-01002-x

Pintrich, P. R. (1999). The role of motivation in promoting and sustaining self-regulated learning. International Journal of Educational Research, 31(6), 459-470. https://doi.org/10.1016/S0883-0355(99)00015-4

Sadler, D. R. (1989). Formative assessment and the design of instructional systems. Instructional Science, 18(2), 119-144. https://doi.org/10.1007/BF00117714

Van Der Kleij, F. M. (2019). Comparison of teacher and student perceptions of formative assessment feedback practices and association with individual student characteristics. Teaching and Teacher Education, 85, 175-189. https://doi.org/10.1016/j.tate.2019.06.010

Vattøy, K. D. (2020). Teachers' beliefs about feedback practice as related to student selfregulation, self-efficacy, and language skills in teaching English as a foreign language. Studies in Educational Evaluation, 64(May 2019), 100828. https://doi.org/10.1016/j.stueduc.2019.100828

Vonderwell, S. K., \& Boboc, M. (2013). Promoting formative assessment in online teaching and learning. TechTrends, 57(4), 22-27. https://doi.org/10.1007/s11528-013-0673-X

Vonderwell, S., Liang, X., \& Alderman, K. (2007). Asynchronous discussions and assessment in online learning. Journal of Research on Technology in Education, 39(3), 309-328. http://files.eric.ed.gov/fulltext/EJ768879.pdf

Wong, J., Baars, M., Davis, D., Van Der Zee, T., Houben, G. J., \& Paas, F. (2019). Supporting self-regulated learning in online learning environments and MOOCs: A systematic review. International Journal of Human-Computer Interaction, 35(4-5), 356-373. https://doi.org/10.1080/10447318.2018.1543084

Xiao, Y., \& Yang, M. (2019). Formative assessment and self-regulated learning: How 
Fatmawati, Purnawarman, and Sukyadi,

Tell : Teaching of English Language and Literature Journal

Vol. 9, No.2, September 2021, Doi: http://dx.doi.org/10.30651/tell.v9i2.9305

formative assessment supports students' self-regulation in English language learning. System, 81, 39-49. https://doi.org/10.1016/j.system.2019.01.004

Yukselturk, E. \& Bulut, S. (2007). Predictors for student success in an online course. Educational Technology \& Society, 10(2), 71-83.

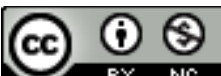

